containing $3.6 \mathrm{~g}$ lysine $/ 1000 \mathrm{kcal} \mathrm{DE}$ were compared. The control diet was based on wheat, soybean meal and mineral and vitamin mixture. Diets 2, 3 and 4 contained wheat (about $80 \%$ ), only $14.8 \%$ soybean meal and were supplemented with $0.53 \%$ lysine $\mathrm{HCl}, 0.07 \%$ methionine and $0,0.10$ and $0.20 \%$ threonine. The four diets contained $23.8,18.3,18.2,17.7 \%$ crude protein and $0.85,0.62,0.71$ and $0.79 \%$ threonine, respectively.

Feed intakes were similar with the four diets $(1034,1043,1065,1072 \mathrm{~g} /$ day $)$. Weight gains were $595,567,611$ and $626 \mathrm{~g} / \mathrm{d}$. The feed conversion ratio of diet $2(1.84)$ was significantly different from that of diets 1,3 and $4(1.74,1.74$ and 1,71$)$. The threonine requirement of weaned piglets between 11 and $25 \mathrm{~kg}$ was therefore estimated at $0.70 \%$ of the diet, i.e. $60 \%$ of the lysine requirement.

\title{
Sulphur amino acid requirements of piglets and growing pigs
}

\author{
Ewa BOROWA, J. LOUGNON, T. KIENER
}

\section{A.E.C. (Service Développement Alimentation Animale), 03600 Commentry}

Four trials were made to study the sulphur amino acid requirements of weaned piglets and growing pigs.

In trial A, 4 diets containing $0.41,0.49,0.57$ and $0.66 \%$ methionine + cystine were fed ad libitum to piglets weighing initially $10 \mathrm{~kg}$. After 28 days of experiment the best performance were obtained with the diet containing $0.49 \%$ methionine + cystine $(1.42 \mathrm{~g} \mathrm{M}+\mathrm{C} / 1000 \mathrm{kcal} \mathrm{DE})$.

In trial $\mathbf{B}$, the digestibility of diets containing 0.41 and $0.57 \%$ methionine + cystine was compared. Digestibility and $\mathrm{N}$ and methionine retention were higher with the diet containing $0.57 \% \mathrm{M}+\mathrm{C}$.

In trial $\mathrm{C}$, diets containing $0.39,0.47,0.55$ and $0.63 \% \mathrm{M}+\mathrm{C}$ were fed ad libitum to 24 growing pigs ( 12 castrated males and 12 females) between 25 and $95 \mathrm{~kg}$ live weight. Between 25 and $45 \mathrm{~kg}$, the best performance were obtained with the diet containing $0.47 \% \mathrm{M}+\mathrm{C}(1.40 \mathrm{~g} /$ $1000 \mathrm{kcal} \mathrm{DE})$. The sulphur amino acid content of diet $1(0.40 \%, 1.20 \mathrm{~g} / 1000 \mathrm{kcal} \mathrm{DE})$ appeared sufficient above $45 \mathrm{~kg}$ live weight.

In trial $\mathrm{D}$, a control diet $(\mathrm{T})$ containing $0.16 \%$ methionine and $0.15 \%$ cystine was compared to a diet $\mathrm{TM}(\mathrm{T}+0.08 \%$ DL-methionine $)$ and a diet $\mathrm{TC}(\mathrm{T}+0.08 \% \mathrm{~L}$-cystine $)$. The trial was made in piglets weighing initially $10 \mathrm{~kg}$ fed ad libitum for 21 days. Methionine supplementation significantly improved performance. Cystine supplementation neither improved weight gain nor feed conversion ratio and decreased feed intake. It was concluded that methionine should represent at least $55 \%$ of sulphur amino acid supply.

\section{Harmful effects of dietary calcium excess in pigs fed a plant-phosphorus-rich diet}

\section{A. POINTILlART, Annie FOURDIN, A. DELMAS}

INRA, Station de Recherches de Nutrition, 78350 Jouy-en-Josas

Dietary calcium excess may decrease phytic $P$ digestibility in hamsters and rats and bone breaking strength in pigs. An experiment was made to compare $\mathrm{Ca}$ and $\mathrm{P}$ balances, mineral content, density and bending moment of bones in pigs fed either a high $(1.4 \%)$ or a normal $(0.6 \%) \mathrm{Ca}$ diet for 2 months. No inorganic $\mathrm{P}$ was added and the total $\mathrm{P}(0.5 \%)$, of which $70 \%$ was phytic, and vitamin $\mathrm{D}_{3}(1000 \mathrm{IU} \mathrm{kg}$ ) contents were the same in both diets. 
The high CA diet had no effect upon phosphorus utilization. Daily amounts of excreted, absorbed and retained calcium were increased whereas $\mathrm{Ca}$ absorption relative to intake was not significantly decreased in high $\mathrm{CA}$ fed pigs.

All signs of phosphorus deficiency such as hypophosphatemia, hypercalcemia, hypophosphaturia and hypercalciura appeared with both high and normal $\mathrm{Ca}$ diets though some of them, especially hypophosphatemia and hypercalcemia, were aggravated by the high $\mathrm{Ca}$ diet. Pigs fed this diet also exhibited decreased density and bending moment of bones without changes in their mineral contents as expressed in percent dry weight. However, ash content relative to bone volume (tibia) was lower and thus, osteoporosis was patent. In addition, higher liver weights and a trend to lower performance were observed with the high $\mathrm{Ca}$ diet. It was concluded that harmful effects of phosphorus deficiency are intensified by dietary $\mathrm{Ca}$ excess which therefore should not be recommended.

\title{
Effect of high and low phosphorus diets upon bones in the growing pig
}

\author{
Annie FOURDIN, Nicole FONTAINE, A. POINTILLART
}

INRA, Station de Recherches de Nutrition, 78350 Jouy-en-Josas

In various species, phosphorus deficiency, but also phosphorus excess may develop mineral and bone disorders. These disorders were studied in the growing pig by comparing the effects of three dietary phosphorus levels (from deficiency to excess) on some mineral metabolism parameters : urinary $\mathrm{Ca}$ and $\mathrm{P}$ excretions, plasma and bone mineral contents, bone bending moment and density. The low $\mathbf{P}$ diet $(0.4 \% \mathrm{P})$ was not supplemented with mineral $\mathrm{P}$, the high $\mathrm{P}$ diet $(1.2 \%$ $\mathrm{P}$ ) contained $0.4 \%$ plant $\mathrm{P}$ and $0.8 \%$ mineral $\mathrm{P}$ and the control diet $(0.7 \% \mathrm{P})$ around $60 \%$ plant $\mathrm{P}$ and $40 \%$ mineral $\mathrm{P}$. Ca $(0.8 \%)$ and vitamin $\mathrm{D}_{3}(500 \mathrm{IU} / \mathrm{kg}$ diet $)$ contents were the same for all diets. Animals were killed after a 7-week period.

P-deficient pigs exhibited hypophosphatemia, hypophosphaturia, higher plasma alkaline phosphatase, hypercalciuria as well as decreased mineral contents (about $-20 \%$ ), density and bending moment of all bones. The high P- diet did not change any plasma parameters, but provoked a very acute hyperphosphaturia, a severe nephrocalcinosis. It also decreased the strength of some bones (tibia, metatarsal), but did not change their mineral contents or density. In conclusion, the disorders in mineral metabolism are more marked with low than with high $\mathbf{P}$ diets. However, high P-related disorders should be taken into account in practical husbandry when formulating diets.

\section{Utilization of tandem rapeseed by weaned piglets and growing-finishing pigs}

\author{
F. GROSJEAN ${ }^{(1)}$, J. CASTAING ${ }^{(2)}$, J. FEKETE ${ }^{(1)}$, F. GATEL ${ }^{(1)}$
}

(I) I.T.C.F., 8, avenue du Président-Wilson, 75116 Paris.

(2) Association Générale des Producteurs de Maïs, 122, boulevard Tourasse, 64000 Pau.

The feeding value of Tandem rapeseed ( $52 \mu$ moles glucosinolate/g defatted dry matter) was studied in diets for $10-25 \mathrm{~kg}$ weaned piglets and for $27-102 \mathrm{~kg}$ growing-finishing pigs. Barley based diets containing either $0-5$ or $10 \%$ raw rapeseed or $20 \%$ extruded rapeseed were compared. These diets were formulated to supply $3.6 \mathrm{~g}$ lysine $/ 1000 \mathrm{kcal} \mathrm{DE}$ to piglets and $2.6 \mathrm{~g}$ to growingfinishing pigs. They were fed ad libitum to piglets and according to a feeding pattern to pigs.

In the piglet trial, energy intake was reduced by 3.4 and $4.1 \%$ with diets containing 5 and $10 \%$ raw rapeseed. With extruded rapeseed, energy intake was reduced by $5 \%$. Feed conversion ratio was similar whatever the diet. Consequently, growth of piglets mainly depended on the level of energy intake. 